Archiv für die gesamte Virusforschung 37, $297-307$ (1972)

(C) by Springer-Verlag 1972

\title{
An Investigation of the Replication of Coronaviruses in Suspension Cultures of L132 Cells
}

\author{
By \\ A. F. Bradburne \\ Common Cold Research Unit, Clinical Research Centre, Harvard Hospital, \\ Salisbury, Wiltshire, England \\ With 6 Figures \\ Received September 6, 1971
}

\begin{abstract}
Summary
A system is described for the study of the multiplication of two coronaviruses, both of human origin. Low efficiences of adsorption and infectious centre formation were observed. The viruses were found to have a $4-6$ hour eclipse phase in $\mathrm{L} 132$ cells at $33^{\circ} \mathrm{C}$. Both viruses were completely inhibited by raising the incubation temperature to $39^{\circ} \mathrm{C}$, and there was also a depression in the yield of virus at $30^{\circ} \mathrm{C}$ compared with control cultures maintained at $33^{\circ} \mathrm{C}$. "Shift" experiments have indicated that the high temperature-sensitive event occurred fairly late on in the replicative cycle, but the time could not be accurately determined.
\end{abstract}

\section{Introduction}

The discovery of ether-labile viruses, serologically unrelated to myxoviruses, in cases of upper respiratory infection in man (TYRRELL and BYNOE, 1965; HAMre and ProckNow, 1966) was the first stage in the recognition of a new group of viruses, found in infections of both man and animals. These viruses were named "coronaviruses" (Nature, 1968) because of their characteristic structure.

Coronavirus virions are pleomorphic, varying in diameter from 800 to $1500 \AA$ (ALMEIDA and TyRRELL, 1967). They are normally covered with a $150 \AA$-thick fringe of club-shaped projections; these are easily removed by either physical or chemical treatments.

Several viruses with this morphology have been isolated from man (e.g. TYRRelu, Bynoe and Hoorn, 1968; MoIntosit et al., 1967; Kapikian et al., 1969). Other viruses of this group include infectious bronchitis virus of chickens (BERRY et al., 1964), murine hepatitis virus (ALMEIDA and TYRRELL, 1967), and transmissible gastroenteritis virus of pigs (TAGIMA, 1970). Most of the human strains and several of the animal strains have been shown to be serologically inter-related (McIntosh et al., 1969; BradbuRne, 1970).

Apart from studies of the replication cycle and morphogenesis of mouse hepatitis virus (David-FerRetra and Manaker, 1965; Chany and Robbe- 
MARIDOR, 1970) and of the comparative morphogenesis of a human coronavirus $(229 \mathrm{E})$ and avian infectious bronchitis virus (HAMre, KINDING and MANN, 1967; BECKER et al., 1967), there are few reports on studies of coronavirus replication. These have awaited the development of a sensitive plaque assay (BRADBURNE and TyRRell, 1969). The results reported here are derived from single-cycle growth curve experiments with two human coronaviruses in suspended tissue culture cells.

\section{Materials and Methods}

\subsection{Viruses}

$229 \mathrm{E}$ virus was received from Dr. D. Hamre and was passaged twice in human embryo lung, once in human embryo tracheal organ eulture and three times in human volunteers (BRADBURNe, BYNOE and TYRRELL, 1967). The virus was recovered in tissue cultures of $\mathrm{L} 132$ cells, from clinical specimens from these volunteers, and was passaged thereafter only in these cells.

LP virus (TYRRELL et al., 1968) was recovered from a nasal washing taken from a volunteer who had been infected with organ culture fluid (3rd passage after the original isolation). It was passaged twice in L 132 cells, 3 times in human diploid lung cells and then 6 times in $\mathrm{L} 132$ cells.

\subsection{Tissue Cultures}

L 132 cells (DAvis, 1960) were grown and maintained as previously described (Bradburne and Tyrrell, 1969). For use in suspension cultures, cells were dispersed with trypsin-versene, washed, and suspended in Eagle's medium containing $2 \%$ foetal calf serum and $0.02 \mathrm{~m} \mathrm{HEPES} \mathrm{buffer} \mathrm{(Sigma).} \mathrm{Cells} \mathrm{were} \mathrm{stirred} \mathrm{magnetically} \mathrm{at} 300$ r.p.rn. for 12 hours at $33^{\circ} \mathrm{C}$ before use. Viable cell counts were made in a haemocytometer on the basis of their resistance to staining with $0.1 \%$ trypan blue.

\subsection{Infectious Centre Assays}

These were performed by diluting infected cells 100 -fold in ice-cold medium; washing these cells three times in similar volumes of medium and then resuspending cells in warm medium. These cells were plated out, at various dilutions, onto drained monolayers of $\mathrm{L} 132$ cells at $37^{\circ} \mathrm{C}$ and were allowed to attach for 60 minutes. The cell monolayers were overlaid with the standard medium for plaque production.

\subsection{Single Cycle Growth Curve Experiments}

Virus stocks were freed from macrocellular debris by centrifugation at $2500 \mathrm{~g}$ for 10 minutes. Virus was warmed to $37^{\circ} \mathrm{C}$ mixed with packed $\mathrm{L} 132$ cells and stirred at $33^{\circ} \mathrm{C}$ for 20 minutes. After this period, cells were washed rapidly three times in icecold medium. Trial experiments showed that the final wash never contained more than $10^{2}$ p.f.u./ml. The cells were counted and resuspended in medium at $33^{\circ} \mathrm{C}$. Unless otherwise stated, an input multiplicity of between 4 and 10 p.f.u./cell was used. The start of the infectious cycle was taken as being half-way through the adsorption period.

Periodically, small samples were withdrawn from infected cell suspensions and either diluted 10 -fold in a stabilizing diluent and frozen, or the cells spun out, washed and disrupted by freezing and thawing. All samples were stored at $-70^{\circ} \mathrm{C}$ before titration.

\section{Results}

\subsection{Efficiency of Formation of Infectious Centres}

In preliminary experiments it was discovered that very little $229 \mathrm{E}$ virus was adsorbed to $\mathrm{L} 132$ cells suspended at $4^{\circ} \mathrm{C}$. The efficiency of infection determined as the ratio of plaque-forming units of virus adsorbed per cell replicating infection 
virus (infectious centre) was very low. Although no greater proportion of virus was adsorbed to cells suspended at $33^{\circ} \mathrm{C}$, the number of infectious centres formed was considerably higher (Table 1).

Table 1. The Formation of Infectious Centres by $229 \mathrm{E}$ Virus in $\mathrm{L} 132 \mathrm{Cells}$ at $4^{\circ}$ and $33^{\circ} \mathrm{C}$ $1.2 \times 10^{6}$ cells suspended in $6 \times 10^{6}$ p.f.u. of $229 \mathrm{E}$ virus at the start of the adsorption

\begin{tabular}{|c|c|c|c|c|c|c|}
\hline & \multirow{2}{*}{$\begin{array}{l}\text { Cell count } / \mathrm{ml} \\
\text { after } \\
\text { adsorption }\end{array}$} & \multirow{2}{*}{$\begin{array}{l}\text { Virus titre/ml } \\
\text { after } \\
\text { adsorption }\end{array}$} & \multirow{2}{*}{$\begin{array}{l}\text { Adsorbed } \\
\text { virus } \\
\text { p.f. u./cell }\end{array}$} & \multirow[t]{2}{*}{$\begin{array}{l}\text { Infectious } \\
\text { centres/ml }\end{array}$} & \multicolumn{2}{|c|}{$\begin{array}{l}\text { Per cent } \\
\text { infected cells b }\end{array}$} \\
\hline & & & & & $a$ & $b$ \\
\hline $\begin{array}{l}12 \text { hours } \\
\text { at } 4^{\circ} \mathrm{C}\end{array}$ & $9.5 \times 10^{4}$ & $5.0 \times 10^{6}$ & 0.8 & $1.8 \times 10^{4}$ & 1.6 & 18.6 \\
\hline $\begin{array}{l}60 \text { minutes } \\
\text { at } 33^{\circ} \mathrm{C}\end{array}$ & $8.1 \times 10^{5}$ & $5.7 \times 10^{6}$ & 0.2 & $2.2 \times 10^{5}$ & 18.0 & 27.2 \\
\hline
\end{tabular}

a "adsorbed virus" were calculated on the cell concentration at the start of the experiment.

b $a=\%$ infected cells calculated on initial cell concentration.

$\mathrm{b}=\%$ infected cells calculated on final cell concentration.

Table 2. The Rate of Formation of Infectious Centres by 229 E Virus at Two Cell Concentrations at $33^{\circ} \mathrm{C}$

\begin{tabular}{|c|c|c|c|c|c|}
\hline \multirow{3}{*}{$\begin{array}{l}\text { Time } \\
\text { (min.) }\end{array}$} & \multirow{3}{*}{$\begin{array}{l}\text { Control } \\
\text { virus } \\
\text { p.f.u. } / \mathrm{ml}^{2}\end{array}$} & \multicolumn{4}{|c|}{ Input Multiplieity } \\
\hline & & \multicolumn{2}{|c|}{4.5 p.f.u./cell } & \multicolumn{2}{|c|}{0.9 p.f.u. $/$ cell } \\
\hline & & $\overline{\mathrm{IC}^{\mathrm{b}} / \mathrm{cell}}$ & $\begin{array}{l}\text { Supernatant } \\
\text { virus (p.f. u. } / \mathrm{ml} \text { ) }\end{array}$ & IC/cell & $\begin{array}{l}\text { Supernatant } \\
\text { virus (p.f.u. } / \mathrm{ml} \text { ) }\end{array}$ \\
\hline 0 & $9 \times 10^{6}$ & 0.00 & $9 \times 10^{6}$ & 0.00 & $9 \times 10^{6}$ \\
\hline 2.5 & & 0.092 & & 0.0021 & \\
\hline 5.0 & & 0.130 & & 0.0045 & \\
\hline 7.5 & & 0.140 & & 0.0037 & \\
\hline 10.0 & & 0.093 & $6 \times 10^{6}$ & 0.0038 & $8.1 \times 10^{6}$ \\
\hline 15.0 & & 0.081 & & 0.0043 & \\
\hline 20.0 & $9 \times 10^{6}$ & 0.065 & $7.5 \times 10^{6}$ & 0.0042 & $4.3 \times 10^{6}$ \\
\hline 40.0 & & 0.090 & & 0.0055 & \\
\hline 60.0 & $7 \times 10^{6}$ & 0.114 & $5.0 \times 10^{6}$ & 0.0048 & $6.0 \times 10^{6}$ \\
\hline 120 & & 0.230 & & 0.0055 & \\
\hline 180 & $3 \times 10^{6}$ & 0.321 & $2.6 \times 10^{6}$ & 0.0062 & $4.0 \times 10^{6}$ \\
\hline
\end{tabular}

Virus concentration $=9 \times 10^{6}$ p.f.u. $/ \mathrm{ml}$

Low cell concentration $=2 \times 10^{6} \mathrm{cells} / \mathrm{ml}$

High cell concentration $=1 \times 10^{7}$ cells $/ \mathrm{ml}$

a "control virus" stirred in cell-free medium at $33^{\circ} \mathrm{C}$.

b infectious centres.

The effect of varying the concentration of cells on the formation of infectious centres was studied. Cells were suspended in the same concentration of virus at two differing concentrations ('Table 2). Frequent estimations of the proportions of infectious centres in each mixture were made during a total incubation period of 180 minutes.

The higher input multiplicity (i.e., the more dilute cell suspension) produced between 2 and 5 -fold more infectious centres at each sampling time. The infectious centre counts reached $30-50 \%$ of maximal levels within 15 minutes of mixing virus and cells, but the levels continued to rise throughout the incubation period. 
Possible explanations of the inefficient infection of $\mathrm{L} 132$ cells by $229 \mathrm{E}$ virus were considered. Firstly, the L 132 cell cultures might be constituted of mixed populations of resistant and susceptible cells. Cloning experiments to confirm this were not practicable. Secondly, the pool of virus used to infect these cells could contain interferon or similar substances which would prevent either the formation or expression of infectious centres. Because of the large volumes of fluid used to wash infected cells, it seemed unlikely that interferon would be active in this

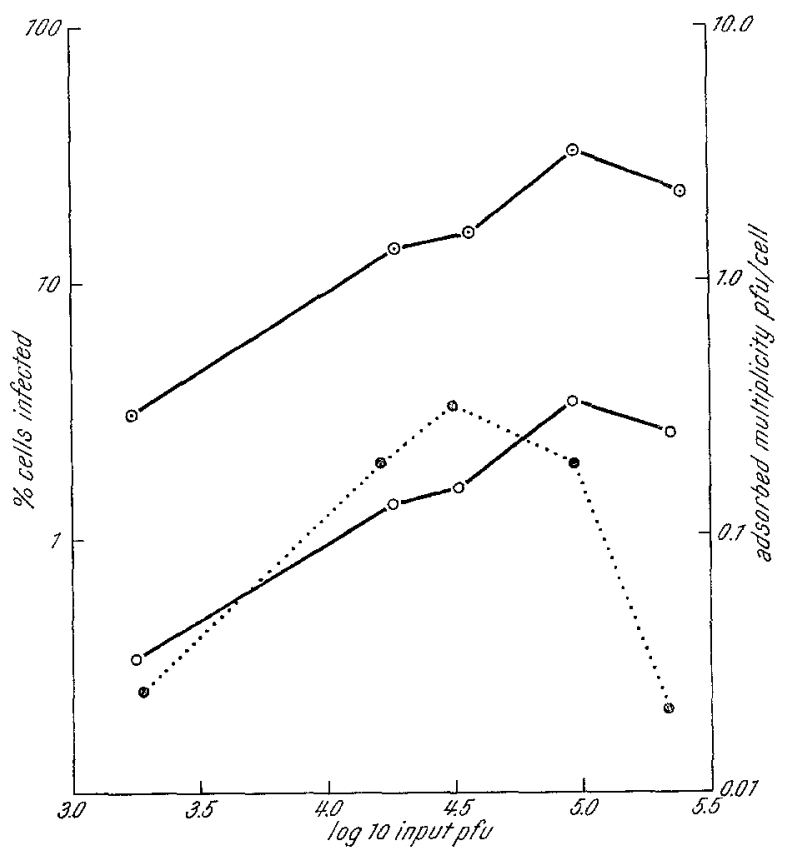

Fig. 1. The theoretical and observed relationships between the adsorbed multiplicity of $229 \mathrm{E}$ virus on $\mathrm{L} 132$ cells and the percentage of cells infected, at various dilutions of infecting virus

$\circ-0$ adsorbed p.f.u./cell; $\odot$ —— $\odot$ theoretical per cent infected cells; $\bullet . . . \cdot$ actual per cent infected

system unless it had become fixed to the cells. To detect any interferon present in the virus pool, the infectivity was destroyed by dialysis against buffer at $\mathrm{pH} 2$ for 12 hours at $4^{\circ} \mathrm{C}$. After subsequent dialysis against $\mathrm{pH} 7.2$ buffer, no interferon-like activity could be detected as judged by the lack of growth inhibition of Sindbis virus in $\mathrm{L} 132$ cells. The third possibility was that some form of autointerference might be operating, as has been found with arboviruses or with vesicular stomatitis virus (CRICK, CARTWRIGHT and BROWN, 1969) under certain conditions. In conditions of autointerference, the normal relationship between the input multiplicity and the efficiency of infection or yield of virus does not operate. Thus, dilution of virus might result in an increased number of infected cells as the interfering activity is diluted out. The relationship between the dilution of a pool of $229 \mathrm{E}$ virus and the ability of the pool to form infectious centres was therefore studied. The adsorption period was 2 hours at $30^{\circ} \mathrm{C}$, after which cells were washed and assayed for infectious centres as described. The experiment shown in Figure 1 used a concentration of $1 \times 10^{6}$ cells per $\mathrm{ml}$ and the input multiplicity was varied 
from 0.82 to 0.0082 p.f.u. $/ \mathrm{ml}$. However, the proportion of infectious centres rose on dilution of the virus pool, reaching a maximum at a 1 in 5 dilution of virus. At a dilution of 1 in 100 the virus produced as many infectious centres as were formed using undiluted virus. Nevertheless, even the maximum number of infectious centre formed was 5 -fold lower than the level predicted from the proportion of virus which had adsorbed to cells.

Table 3. Concentrations of Viruses, Cells; and Other Data for the Grouth Curves Shown in Figure 2

\begin{tabular}{lll}
\hline & I.P & $229 \mathrm{E}$ \\
\hline Total number of cells & $4.7 \times 10^{7}$ & $3.3 \times 10^{7}$ \\
$\begin{array}{l}\text { Virus input (total p.f.u.) } \\
\text { Input Multiplicity }\end{array}$ & $2.5 \times 10^{8}$ & $1.1 \times 10^{8}$ \\
$\begin{array}{l}\text { (p.f.u./cell) } \\
\text { Adsorbed Multiplicity }\end{array}$ & 0.28 & 3.3 \\
$\begin{array}{l}\text { (p.f.u./cell) } \\
\text { Total Infectious Centres }\end{array}$ & $6.4 \times 10^{6}$ & 0.052 \\
(IC) & 13.0 & $3.7 \times 10^{6}$ \\
$\begin{array}{l}\text { Percentage Infected } \\
\text { Intracellular virus titre }\end{array}$ & $1.8 \times 10^{4}$ & 11.2 \\
(p.f.u./ml) at 10 hours & $1.6 \times 10^{3}$ & $2.2 \times 10^{4}$ \\
$\begin{array}{l}\text { Extracellular virus titre } \\
\text { (p.f.u./ml) at 10 hours }\end{array}$ & $1.0 \times 10^{4}$ \\
Maximum yield (p.f.u./IC) & 1.3 & 2.1 \\
\hline
\end{tabular}

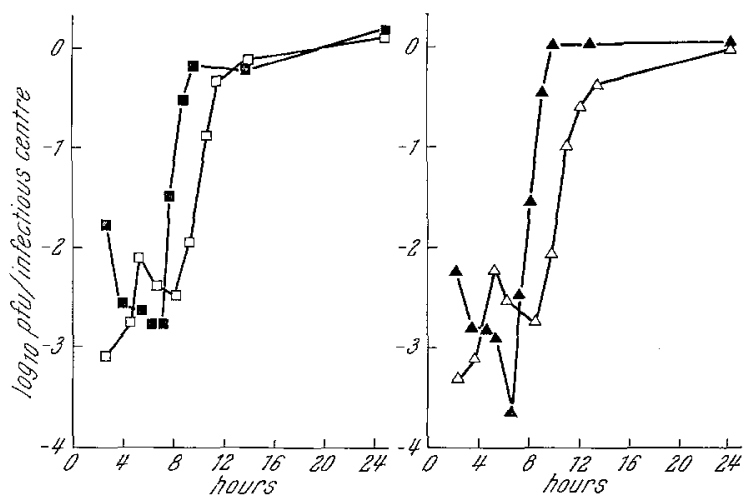

Fig. 2. The production of cell-associated and supernatant $229 \mathrm{E}$ and $\mathrm{LP}$ viruses in $\mathrm{L} 132$ cells at $33^{\circ} \mathrm{C}$ and $\mathrm{pH} 7.2$ (see also Table 3)

- $229 \mathrm{E}$ cell-associated virus; $\square-\square 229 \mathrm{E}$ supernatant virus; $-\triangle \longrightarrow \mathrm{LP}$ L cell-associated virus;

\subsection{The Time-Sequence of Viral Replication in L 132 Cell Cultures}

Using the standard conditions, detailed in the "Materials and Methods", the growth curves of both $229 \mathrm{E}$ and LP viruses in L 132 cells were investigated. The production of cell-associated and cell-free virus was measured; infectious centres and adsorbed multiplicities were also estimated. The data for these experiments are given in Table 3 and the results displayed in Figure 2. 
The "eclipse" phase (i.e. the interval between adsorption and detectable virus formation) was $4-7$ hours for both viruses, and averaged about 4.5 hours. Because of the low proportion of cells initially infected, multiple cycles of infection were likely, but in fact did not seem to occur since virus titres reached a maximum at 10-12 hours and stayed at that level for the remaining 12 hours of the experiments. This only applied to the cell-associated virus; cell-free virus titres continued to rise throughout the period of observation. At 10 hours after infection there was 10-fold less cell-free than cell-associated virus; but with $229 \mathrm{E}$ virus, the virus was released as rapidly as it was formed. In all cases the final yield of virus was very low ( $2-6$ p.f. u./infectious centres).

\subsection{The Effects of Temperature on Virus Replication}

It has been shown (STOTT and HEATH, 1969) that rhinoviruses (the other main group of viruses implicated in upper respiratory tract disease in man) have their replication inhibited by temperatures above $39^{\circ} \mathrm{C}$. This might be the result of the low physiological temperature of their natural environment, the nasal epithelium. Characteristically, both rhinoviruses and coronaviruses are more easily isolated in tissue cultures maintained at $33^{\circ}$ rather than $37^{\circ} \mathrm{C}$.

During the development of the plaque assay for the $229 \mathrm{E}$ virus the effects of temperatures ranging from $30^{\circ}$ to $39^{\circ} \mathrm{C}$ on the development of plaques were investigated. After the normal processes of inoculation and overlaying, monolayers of $\mathrm{L} 132$ cells were maintained at various temperatures by submersion in waterbaths. After 4 and 5 days of incubation, plates were removed, fixed and stajned. Table 4 shows that no plaques were formed at $30^{\circ}$ or $39^{\circ} \mathrm{C}$ during this period. The plaque counts at $33^{\circ}$ and $35^{\circ} \mathrm{C}$ were similar, but at $37^{\circ} \mathrm{C}$ there were less plaques $(60 \%$ for $229 \mathrm{E}$ and $50 \%$ for LP).

Table 4. The Effects of Various Temperatures Between $30^{\circ}$ and $39^{\circ} \mathrm{C}$ on the Production of Plaques in L 132 Cells by $229 E$ and LP Viruses

\begin{tabular}{|c|c|c|c|c|}
\hline \multirow[t]{3}{*}{ Temperature $\left({ }^{\circ} \mathrm{C}\right)$} & \multicolumn{4}{|c|}{ Plaque Count (average of 3 plates) } \\
\hline & \multicolumn{2}{|c|}{ Virus $229 \mathrm{E}$} & \multicolumn{2}{|c|}{ Virus LP } \\
\hline & \multicolumn{2}{|c|}{ Incubation Period } & $\begin{array}{l}\text { Tncubat } \\
\mathbf{4} \text { days }\end{array}$ & $\begin{array}{c}\text { Period } \\
5 \text { days }\end{array}$ \\
\hline 30 & 0 & 0 & 0 & 0 \\
\hline 33 & 66 & 89 & 26 & 29 \\
\hline 35 & 49 & 86 & 19 & 24 \\
\hline 37 & 6 & 33 & 8 & 14 \\
\hline 39 & 0 & 0 & 0 & 0 \\
\hline
\end{tabular}

To investigate the effects of temperature on the replication of coronaviruses during a single infectious cycle, cells were infected with either $229 \mathrm{E}$ or LP viruses at $33^{\circ} \mathrm{C}$ and then divided into aliquots which were maintained at various temperatures between $30^{\circ}$ and $39^{\circ} \mathrm{C}$. Figures 3 and 4 shows the results, and the eclipse periods and 12 hour yields are given in Table 5 .

The effects of this range of temperature on the two viruses was basically the same. The depression in the yield of LP virus at $30^{\circ}$ compared with that at $33^{\circ} \mathrm{C}$ 
Replication of Coronaviruses in Suspension Cultures of L 132 Cells

Table 5. The Length of the Eclipse Period and the Maximum Yield of $229 E$ and LP Viruses Grown in L 132 Cells at Various Temperatures (see also Figs. 3 and 4)

\begin{tabular}{|c|c|c|c|c|}
\hline \multirow{2}{*}{$\begin{array}{l}\text { Temperature } \\
\left({ }^{\circ} \mathbf{C}\right)\end{array}$} & \multicolumn{2}{|l|}{$229 \mathrm{E}$} & \multicolumn{2}{|l|}{$L P$} \\
\hline & $\begin{array}{l}\text { Eclipse } \\
\text { Period } \\
\text { (hours) }\end{array}$ & $\begin{array}{l}\text { Yield } \\
\text { (p.f.u./IC) }\end{array}$ & $\begin{array}{l}\text { Eclipse } \\
\text { Period } \\
\text { (hours) }\end{array}$ & $\begin{array}{l}\text { Yield } \\
\text { (p.f.u./IC) }\end{array}$ \\
\hline 30 & 8 & $1.5 \times 10^{-1}$ & 10 & $5.5 \times 10^{-2}$ \\
\hline 33 & 6 & 1.6 & 7 & 2.9 \\
\hline 35 & 5 & 1.8 & 6 & 2.9 \\
\hline 37 & 6 & $1.9 \times 10^{-1}$ & 7 & $1.3 \times 10^{-1}$ \\
\hline 39 & $>24$ & $<1.0 \times 10^{-5}$ & $>24$ & $<1.0 \times 10^{-4}$ \\
\hline
\end{tabular}

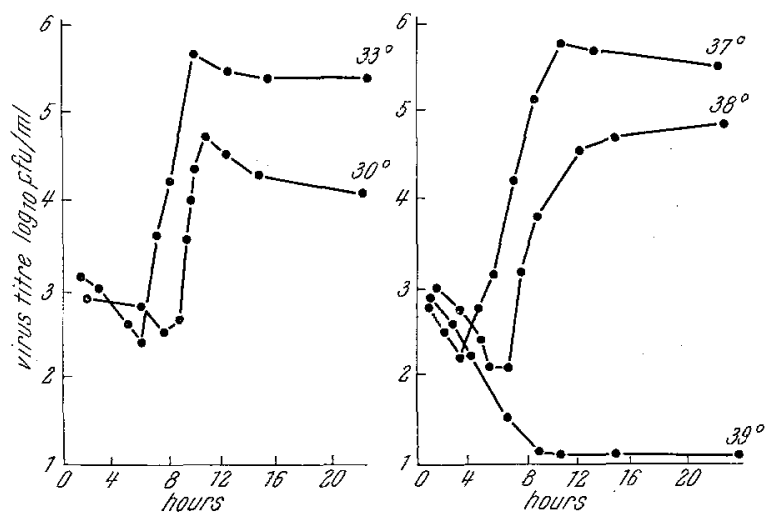

Fig. 3. The growth of $229 \mathrm{E}$ virus in suspended cell cultures at various temperatures, showing the cut-off in virus production between $38^{\circ}$ and $39^{\circ} \mathrm{C}$ (see also Table 5)

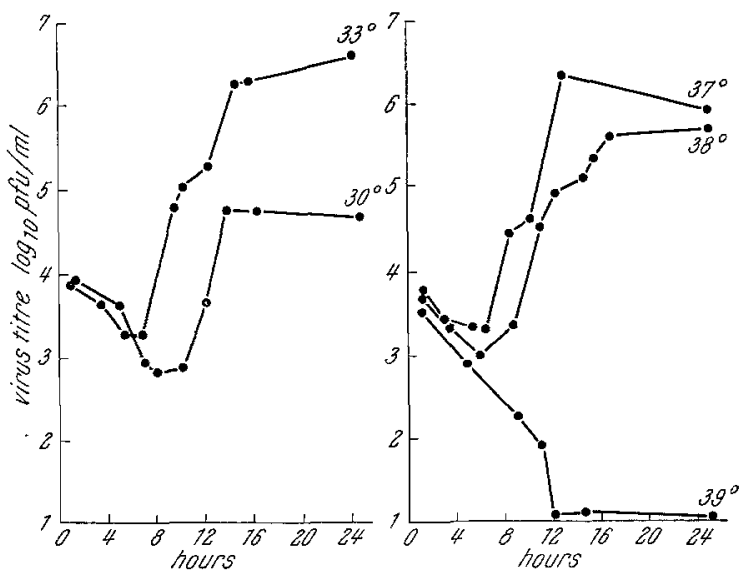

Fig. 4. The growth of $L P$ virus in suspended eultures of $L 132$ cells, under similar conditions for the $229 \mathrm{E}$ growth curves (see previous Figure; see also Table 5)

was 140-fold; the corresponding depression for $229 \mathrm{E}$ was only 20 -fold. The eclipse phases were about 1 hour shorter at $35^{\circ}$ than at $33^{\circ} \mathrm{C}$; for $\mathrm{LP}$ it was lengthened from 7 hours at $33^{\circ}$ to 11 hours at $30^{\circ} \mathrm{C}$. For $229 \mathrm{E}$ virus the corresponding increase was from 6 hours to 8 hours. There was substantial inhibi- 
tion of both viruses at $38^{\circ}$ and complete inhibition at $39^{\circ} \mathrm{C}$. Thus, there was evidence of both high $\left(39^{\circ}\right)$ and low $\left(30^{\circ}\right)$ temperature suppression of these viruses.

\subsection{Attempts to Locate the Timing of the $39^{\circ}$-Sensitive Event}

Because of the marked depression in the yields of $229 \mathrm{E}$ and LP viruses at $39^{\circ} \mathrm{C}$, it was possible to perform "shift" experiments in which infected cell cultures were moved from a "permissive" $\left(33^{\circ}\right)$ to a "restrictive" $\left(39^{\circ}\right)$ temperature and vice versa.

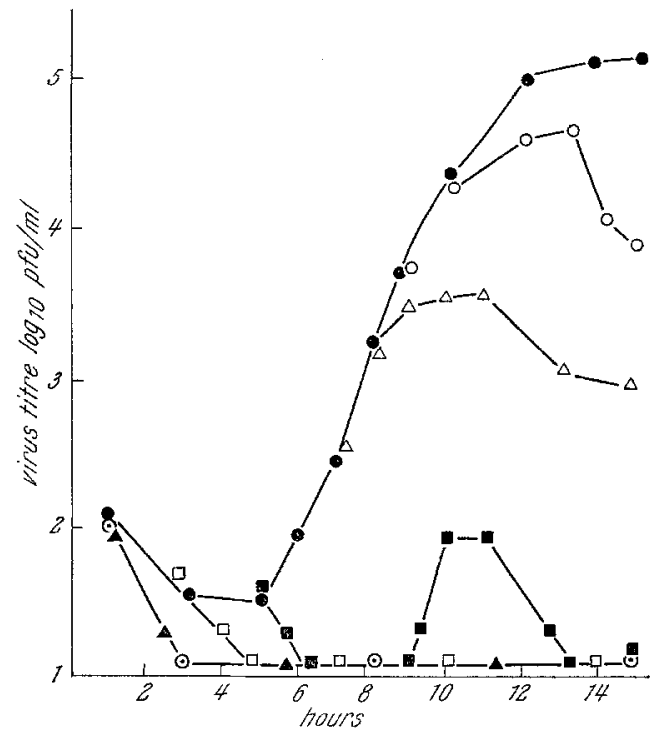

Fig. 5. The effects on the formation of $229 \mathrm{E}$ virus when infected cultures of $\mathbf{L} 132$ cells are renoved from $33^{\circ}$ to $39^{\circ} \mathrm{C}$ at various times after infection
$-33^{\circ}$ only, $\odot-\odot 39^{\circ}$ only

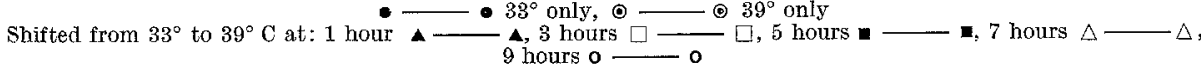

The results of a "shift-up" experiment with 229 E virus are shown in Figure 5. Replicate suspension cultures of infected L 132 cells were shifted from $33^{\circ}$ to $39^{\circ} \mathrm{C}$ at various intervals up to 9 hours after infection. Cell suspensions were sampled throughout the experiment at hourly intervals. Shifting infected cells to $39^{\circ} \mathrm{C}$ within 5 hours of infection prevented any subsequent formation of infectious virus. The cell suspension shifted at 5 hours produced a small quantity of virus $\left(10^{2}\right.$ p.f.u. $/ \mathrm{ml}$ ). The rate of virus production in the cell suspension which was shifted to $39^{\circ} \mathrm{C}$ at 7 hours was similar to that of the control $\left(33^{\circ}\right)$ suspension for the next two hours, but reached an early plateau. The culture shifted at 9 hours produced only $20 \%$ of the control yield of virus.

For "shift-down" experiments, cells were infected at $33^{\circ} \mathrm{C}$ and immediately transferred to $39^{\circ} \mathrm{C}$ after subdivision into replicate suspensions. They were then moved back to $33^{\circ} \mathrm{C}$ at various times up to 9 hours. The duration of the eclipse period increased proportionately with the increasing delay in shifting the cultures back to the permissive temperature (Fig. 6). Also, after a minimum of 1 hour at $39^{\circ} \mathrm{C}$, all cultures produced a reduced yield when compared with a control which 
had been kept at $33^{\circ} \mathrm{C}$ only. The reasons for the extra depression in the yield of LP virus in the culture shifted at 5 hours (Fig. 6) are not known.
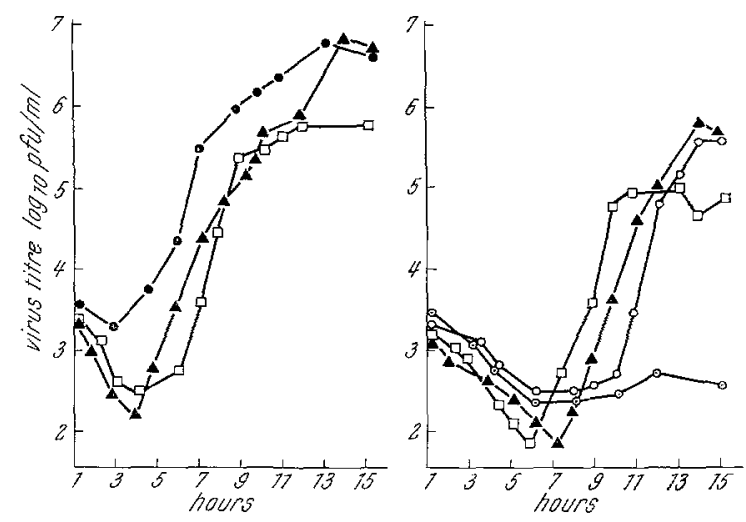

Fig. 6. The results of a "shift-down" experiment with LP virus in which infected L 132 cells were transferred from $39^{\circ}$ to $33^{\circ} \mathrm{C}$ at various times after infection

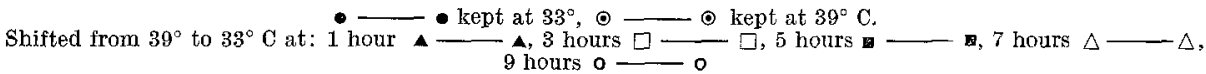

\section{Diseussion}

\subsection{Adsorption of Virus and Formation of Infectious Centres}

In all the experiments reported in these studies, the initial proportion of L 132 cells infected with either of the two coronaviruses studied was low and rarely exceeded $20 \%$. The adsorption of virus at $4{ }^{\circ} \mathrm{C}$ was very poor; under similar conditions L 132 cells adsorbed rhinoviruses much more efficiently and gave rise to the expected number of infectious centres (Sтотт and HEaTH, 1969). Even at $33^{\circ} \mathrm{C}$ the adsorption of coronaviruses was still relatively inefficient and the numbers of infectious centres formed were below the theoretical levels predicted from the adsorbed multiplicity. This multiplicity could be artificially high if thermal inactivation of virus occurred during the adsorption period. However, virus maintained in cell-free medium for the same period at $33^{\circ} \mathrm{C}$ showed no detectable loss of infectivity. On the basis of trypan blue staining very few dead cells were detected in cell suspensions before virus was added. Therefore adsorption to dead cells was considered unlikely. Whether or not some portion of the cells were infected but unable to produce infectious virus, was not known.

The experimental evidence indicates that some form of autointerference may be operating under the conditions of adsorption. One characteristic of coronaviruses appears to be their high physical to infectious particle ratio which may exceed $10^{4}$ (Mrs. J. D. Almeida, personal communication). An autoinhibition effect has been observed when undiluted egg fluids containing infectious bronchitis virus are passaged serially (McDougal, personal communication). The large proportion of uninfectious virus particles may be interfering with the adsorption or replication of the remainder. This could involve the direct blocking of cell receptors by inactive virus or some viral component. Purified preparations of coronaviruses seem to contain large numbers of particles with a structure which resembles the 
club-shaped projections of the viruses; these might be the receptor-blocking antigens.

\subsection{The Viral Growth Cycle}

There appears to be a reasonable correlation between the sequence of events determined in these studies and those made on other coronaviruses. Infectious LP and $229 \mathrm{E}$ viruses reappeared in $\mathrm{L} 132$ cells between 4 and 6 hours after infection, at $33^{\circ} \mathrm{C}$. BEcker et al. (1967) first observed $229 \mathrm{E}$ and AIB particles in WI-38 cells, and in cells of the chorioallantoic membrane of 10-day-old eggs, respectively, after a period of 10-12 hours postinfection.

David-Ferreira and Manaker (1965) were able to detect particles of mouse hepatitis virus 7 hours after infection of NCTC 1469 mouse liver cells in suspension culture.

\subsection{The Effects of Temperature}

The absence of virus replication at $39^{\circ} \mathrm{C}$ could be due to a high rate of thermal inactivation at this temperature. However, separate experiments have determined that the rate of thermal inactivation at $39^{\circ} \mathrm{C}$ (in a protein-free medium) was $0.18 \log$ p.f.u./hour, less than twice the rate at $33^{\circ} \mathrm{C}$. The yields of viruses from cells maintained at $39^{\circ} \mathrm{C}$ were at least 500 -fold less than at $33^{\circ} \mathrm{C}$, and there was also a 100 -fold depression in yields at $30^{\circ} \mathrm{C}$ for both $\mathrm{LP}$ and $229 \mathrm{E}$ viruses. It was concluded that the effects of temperature were mainly on virus replication within the cell.

The shift experiments failed to accurately locate any one temperature sensitive event which is subject to inhibition at $39^{\circ} \mathrm{C}$. The shifting of cultures from $33^{\circ}$ to $39^{\circ} \mathrm{C}$ earlier than 5 hours after infection completely cuts off virus production, therefore the sensitive reaction would appear to be operational late in the eclipse phase. Shifting of infected cultures after the normal eclipse phase still resulted in a depressed yield which would suggest an inhibition of a continuing process, rather than of a specific stage in virus replication. The shift-down experiments indicate that the viral genome is able to survive in some intracellular form for at least 9 hours but, because of the reduced virus yield, the genome may be subjected to increased degradation by cellular cathepsins (LWOFF, 1969). Some stages in virus replication seem to be able to proceed at $39^{\circ} \mathrm{C}$ as there is, on the average, only a $11 / 2$ hour period after shifting infected L 132 cells from $39^{\circ}$ to $33^{\circ} \mathrm{C}$, before new infectious virus is formed and the normal eclipse period does not have to elapse before the formation of complete virus.

Because of the non-optimal conditions, such as the low percentage of cells infected initially, the interpretation of these experiments can only be provisional until conditions of synchronious infection and replication of these viruses can be obtained.

\section{Acknowledgments}

The author would like to thank Miss B. A. Somerset for her invaluable technical assistance, and also acknowledges the advice and assistance given by Dr. E.J. Stott and Dr. D. A.J. Tyrrell.

\section{References}

Almeida, June, D., and D. A.J. Tyregle: The morphology of three previously uncharacterized respiratory viruses that grow in organ cultures. J. Virol. 1, 175 (1967). 
Becker, W. B., K. MoImtosh, J. H. Dees, and R. M. Chanock: Morphogenesis of avian infectious bronchitis virus and a related human virus (Strain $229 \mathrm{E}$ ). J. Virol. 1,1019 (1967).

Berry, D. M., J. G. Cruichsmank, H. P. Chu, and R. J. H. Wells: The structure of infectious bronchitis virus. Virology $\mathbf{2 3}, 403$ (1964).

Bradburne, A. F., H. L. Bynoe, and D. A.J. TyrrelL: Effects of a "new" human respiratory virus in volunteers. Brit. med. J. $\$ 3,767$ (1967).

BradbURne, A.F., and D.A.J. TrRekLL: The propagation of "coronaviruses" in tissue-culture. Arch. ges. Virusforsch. 28, 133 (1969).

BradburNe, A. F. : Antigenic relationships amongst coronaviruses. Arch. ges. Virusforsch. $31,352(1970)$.

ChanY, C., and F'. RoBbe-MARIDor: Enhancing effect of the murine sarcoma virus (MSV) on the replication of the mouse hepatitis virus (MHV) in vitro. Proc. Soc. exp. Biol. (N. Y.) 131, 30 (1970).

Crick, Joan., B. Cartwright, and F. Brown: Studies on the interference phenomenon in vesicular stomatitis replication. Arch. ges. Virusforsch. 27, 235 (1969).

David-Ferreira, J.F., and R. H. MaNaKer: An electron microscope study of the development of a mouse hepatitis virus in tissue culture cells. J. Cell Biol. 24, 57 (1965).

DAvIS, E. V.: Continuous cultivation of isogenous cell lines from the human embryo. Fed. Proc. 19, 57 (1960).

Hamre, D., D. A. Krndic, and J. ManN: Growth and intracellular development of a new respiratory virus. J. Virol. 1, $810(1967)$.

HAMRE, D., and $\mathfrak{J}$. J. Procknow: A new virus isolated from the human respiratory tract. Proc. Soc. exp. Biol. (N. Y.) 121, 190 (1966).

Kapikian, A. Z., H. D. James, Sarah J. Kelly, Jane H. Dees, H. C. Turner, K. MoIntosh, H. W. Kim, R. H. Parrott, M. M. Vincent, and R. M. Chanock: Isolation from man of "avian infectious bronchitis virus-like" viruses (Coronaviruses) similar to $229 \mathrm{E}$ virus, with some epidemiological observations. J. infect. Dis. 119, 282 (1969).

LwofF, A.: Death and transfiguration of a problem. Bact. Rev. 33, 390 (1969).

MoIntosh, K., Jane H. Dees, W. B. Becker, A. Z. Kapikian, and R. M. Chanoch: Recovery in tracheal organ cultures of novel viruses from patients with respiratory disease. Proc. nat. Acad. Sci. (Wash.) 57, 933 (1967).

McIntosh, K., A. Z. Kapiktan, Kathleen A. Hardison, Janet W. Hartiey, and R. M. Chanock: Antigenic relationships among the coronaviruses of man and between human and animal coronaviruses. J. Immunol. 102, 1109 (1969).

Nature (Lond.) Coronaviruses. 220, 650 (1968).

StотT, E.J., and G.F. НЕAтh: Factors affecting the growth of Rhinovirus 2 in suspension cultures of L 132 cells. J. gen. Virol. 6, 15 (1970).

TAлTMA, M.: Morphology of transmissible gastroenteritis virus of pigs: a possible member of coronaviruses. Arch. ges. Virusforsch. 29, 105 (1970).

TYRRELL, D. A.J., and M. L. BYNOE : Cultivation of a novel type of common cold virus in organ cultures. Brit. med. J. i, 1467 (1965).

Tyrrell, D. A.J., M. L. BynoE, and B. Hoors: Cultivation of "difficult" viruses from patients with common colds. Brit. med. J. i, 606 (1968).

Author's address: Dr. A. F. Bradburne, The John Curtin School of Medical Research, The Australian National University, Microbiology Department, P.O.Box 334, Carberra City, A.C.T. 2601, Australia. 